\title{
Mu opioid receptor and orexin/hypocretin mRNA levels in the lateral hypothalamus and striatum are enhanced by morphine withdrawal
}

\author{
Yan Zhou, Jacob Bendor, Lauren Hofmann, Matthew Randesi, Ann Ho and Mary Jeanne Kreek \\ Laboratory of the Biology of Addictive Diseases, The Rockefeller University, 1230 York Avenue, New York, New York 10021, USA \\ (Requests for offprints should be addressed to Y Zhou; Email: yan.zhou@rockefeller.edu)
}

\begin{abstract}
In this study, we investigated the effects of acute morphine administration, chronic intermittent escalating-dose morphine administration and spontaneous withdrawal from chronic morphine on mRNA levels of mu opioid receptor (MOP-r), and the opioid peptides pro-opiomelanocortin (POMC) and preprodynorphin (ppDyn) in several key brain regions of the rat, associated with drug reward and motivated behaviors: lateral hypothalamus (lat.hyp), nucleus accumbens (NAc) core, amygdala, and caudate-putamen $(\mathrm{CPu})$. There was no effect on MOP-r mRNA levels in these brain regions $30 \mathrm{~min}$ after either a single injection of morphine $(10 \mathrm{mg} / \mathrm{kg}$, i.p.) or chronic intermittent escalating-dose morphine (from $7.5 \mathrm{mg} / \mathrm{kg}$ per day on day 1 up to $120 \mathrm{mg} / \mathrm{kg}$ per day on day 10). Activation of the stress-responsive hypothalamic-pituitary-adrenal axis by $12 \mathrm{~h}$ withdrawal from chronic morphine was confirmed; both POMC mRNA levels in the anterior pituitary and plasma
\end{abstract}

adrenocorticotropic hormone levels were significantly elevated. Under this withdrawal-related stress condition, there was an increase in MOP-r mRNA levels in the lat.hyp, NAc core, and $\mathrm{CPu}$. Recent studies have demonstrated a novel role for the lat.hyp orexin (or hypocretin) activation in both drug-related positive rewarding, and withdrawal effects. Around $50 \%$ of lat.hyp orexin neurons express MOP-r. Therefore, we also examined the levels of lat.hyp orexin mRNA, and found them increased in morphine withdrawal, whereas there was no change in levels of the lat.hyp ppDyn mRNA, a gene coexpressed with the lat.hyp orexin. Our results show that there is an increase in $M O P-r$ gene expression in a region-specific manner during morphine withdrawal, and support the hypothesis that increased lat.hyp orexin activity plays a role in morphine-withdrawalrelated behaviors.

Journal of Endocrinology (2006) 191, 137-145

\section{Introduction}

Endogenous opioidergic systems, especially pro-opiomelanocortin (POMC)-derived $\beta$-endorphin, exert inhibitory effects on the hypothalamic-pituitary-adrenal (HPA) axis in both humans (Volavka et al. 1979, Schluger et al. 1998) and rodents (Eisenberg 1980, Zhou et al. 2005). $\beta$-Endorphin immunoreactive (ir) fibers and corticotropin-releasing hormone $(\mathrm{CRH})$-ir perikarya are colocalized in the paraventricular nucleus (PVN) of the hypothalamus (e.g. Pilcher \& Joseph 1984). To exert a tonic inhibition on CRH neuronal activity, it is suggested that $\beta$-endorphin acts primarily at the mu opioid receptor (MOP-r; Nikolarakis et al. 1987). In the arcuate nucleus of the mediobasal hypothalamus, MOP-rs are presynaptic autoreceptors in $\beta$-endorphin neurosecretory neurons that regulate the release of $\beta$-endorphin from these cells (Nikolarakis et al. 1987, Kelly et al. 1990). It has been reported that a downregulation of MOP-r binding following chronic morphine treatment is associated with decreased potency and/or efficacy of MOP-r agonists in mediobasal hypothalamic neurosecretory neurons (including $\beta$-endorphin and dopamine neurons) in the guinea pig (Zhang et al. 1996). In conjunction with this finding, MOP-r mRNA levels are found

to decrease in the mediobasal hypothalamus of the female guinea pig following chronic morphine treatment (Ronnekleiv et al. 1996). Chronic methadone maintenance in the male rat, however, does not alter the MOP-r mRNA levels in the hypothalamus, nucleus accumbens (NAc) core, or caudateputamen $(\mathrm{CPu}$; Leri et al. 2006).

In the male rat, acute ( 1 or 2 day) administration of morphine stimulates $\beta$-endorphin and adrenocorticotropic hormone (ACTH) secretion from the anterior pituitary, and then corticosterone secretion from the adrenal gland, while tolerance (even suppression) of HPA activity develops in the rat following long-term (5 days or longer) morphine treatment (Buckingham \& Cooper 1984, Ignar \& Kuhn 1990, Martinez et al. 1990, Zhou et al. 1999). Both spontaneous and opioid antagonist-precipitated morphinewithdrawal results in an elevation of plasma $\beta$-endorphin, ACTH, and glucocorticoid levels in both rodents (Lightman \& Young 1988, Ignar \& Kuhn 1990, Martinez et al. 1990) and humans (Kreek \& Hartman 1982, Kosten et al. 1986, Culpepper-Morgan \& Kreek 1997). In humans, an earlier study from our laboratory has found that naloxoneprecipitated withdrawal in opiate-dependent individuals results in an increase in HPA hormonal release, which 
precedes subjective and objective symptoms of withdrawal (Culpepper-Morgan \& Kreek 1997).

The lateral hypothalamus (lat.hyp) is an important brain region for reward and other motivated behaviors (e.g. Harris et al. 2005). However, the question of whether morphine withdrawal influences $M O P-r$ gene expression in the lat.hyp has not yet been studied. An administration paradigm of chronic intermittent escalating-dose morphine was recently developed in our laboratory in order to mimic the multiple and escalating doses that human heroin abusers seek daily to achieve rewarding effects and to prevent symptoms of withdrawal from a $12 \mathrm{~h}$ between-dose interval (Kreek et al. 2002). The present studies were, therefore, undertaken to determine the effects of acute single-dose morphine administration, 10-day chronic intermittent escalating-dose morphine administration or its $12 \mathrm{~h}$ spontaneous withdrawal, on MOP-r mRNA levels in the lat.hyp. We also examined the effects of this morphine withdrawal on mRNA levels of MOP-r in several other brain regions associated with drugseeking or drug-withdrawal behaviors, including the NAc core, amygdala, and $\mathrm{CPu}$. In the medial portion of the hypothalamus and anterior pituitary, the regions associated with HPA regulation, we also measured POMC and $\mathrm{CRH}$ type 1 receptor (CRH-R1) mRNA levels.

The orexins/hypocretins are neuropeptides that are mainly expressed in cells of the lat.hyp (de Lecea et al. 1998). It has been established that the hypothalamic orexins (orexins A and B) are involved in the regulation of sleep, arousal, feeding, and stress (Saper et al. 2005, Winsky-Sommerer et al. 2005). There is a growing body of evidence suggesting a novel role for the orexins in regulation of drug seeking-related behaviors. For example: (1) the studies of acute morphine administration have shown an attenuated increase in extracellular dopamine levels in the NAc by orexin receptor blockade in the ventral tegmental area (Narita et al. 2006). (2) Animal behavioral studies suggest that the interaction between orexins and their receptors may underlie motivated behaviors induced by morphine, cocaine, or food (Boutrel et al. 2005, Harris et al. 2005, Borgland et al. 2006), and morphine-withdrawalrelated behaviors (Georgescu et al. 2003). In the present studies, therefore, we also determined whether acute or chronic morphine administration, spontaneous morphine withdrawal would affect orexin mRNA expression in the lat.hyp.

\section{Materials and Methods}

\section{Animal maintenance and treatment}

Male Fischer rats (190-220 g, Charles River Labs, Kingston, NY, USA) were housed individually in a stress-minimized facility with free access to water and food. Animals were adapted to a standard $12 \mathrm{~h}$ light: $12 \mathrm{~h}$ darkness cycle (lights off from 0700 to $1900 \mathrm{~h}$ ) for 7 days.
Experiment I: acute morphine Animals received i.p. injections of saline $(1 \mathrm{ml} / \mathrm{kg})$ for 7 days in their home cages. On the experimental day, animals were randomly assigned to two treatment groups, and given either one single injection of morphine $(10 \mathrm{mg} / \mathrm{kg})$ or an equal volume of saline $(1 \mathrm{ml} / \mathrm{kg})$ in their home cages, beginning $4 \mathrm{~h}$ after the start of their daily dark cycle $(1100 \mathrm{~h})$. Thirty minutes after the injection, rats were exposed to $\mathrm{CO}_{2}$ for $15 \mathrm{~s}$ and killed by decapitation.

The time of killing is around the peak time point of plasma $\mathrm{ACTH}$ and corticosterone levels during the day in the rat. The morphine dose chosen was based on a pilot study, in which a single $10 \mathrm{mg} / \mathrm{kg}$ dose, but not $5 \mathrm{mg} / \mathrm{kg}$, was observed to moderately increase ACTH and corticosterone levels in morphine naïve rats (Y Zhou, J Bendos \& L Hofmann, unpublished observations).

Experiment II: chronic morphine and its acute withdrawal Animals were randomly assigned to two groups, and given either morphine or an equal volume of saline $(1 \mathrm{ml} / \mathrm{kg})$ three times daily with two 6-h intervals and one $12-\mathrm{h}$ interval, beginning $4 \mathrm{~h}$ after the start of their daily dark cycle $(1100,1700$, and $2300 \mathrm{~h})$ for 10 days. The paradigm of chronic (10 days) escalating-dose morphine included a dose increase every second day: animals received $7 \cdot 5(3 \times 2 \cdot 5) \mathrm{mg} / \mathrm{kg}$ per day on days $1-2,15(3 \times 5 \cdot 0) \mathrm{mg} / \mathrm{kg}$ per day on days $3-4,30(3 \times 10)$ $\mathrm{mg} / \mathrm{kg}$ per day on days $5-6,60(3 \times 20) \mathrm{mg} / \mathrm{kg}$ per day on days $7-8$, and $120(3 \times 40) \mathrm{mg} / \mathrm{kg}$ per day on days $9-10$.

We conducted our studies in two separate experiments, due to timing, space, and manpower requirements involved in such chronic experiments: (1) Experiment IIa: chronic (10 days) intermittent escalating-dose morphine (CIEM). (2) Experiment IIb: acute spontaneous withdrawal from chronic intermittent escalating-dose morphine (ASWCIEM). We had two separate saline-control groups, one for each experiment, which were by necessity identical. In each experiment, animals were assigned to two groups of six animals. In Experiment IIa, (1) CIEM experimental group: the animals received intermittent escalating-dose morphine for 10 days (administration paradigm as detailed earlier) and then received the last injection of morphine at a final dose $(40 \mathrm{mg} / \mathrm{kg})$ at $1100 \mathrm{~h}$ on day 11. (2) CIEM control: the animals received identical injections of saline for 10 days and then received the last injection of saline at $1100 \mathrm{~h}$ on day 11 . In Experiment IIb, (1) ASWCIEM experimental group: the animals received chronic escalating-dose morphine for 10 days as described in Experiment I, and then received a last injection of saline (instead of morphine) at $1100 \mathrm{~h}$ on day 11. (2) ASWCIEM control: the animals received chronic saline for 10 days and then received the last injection of saline at $1100 \mathrm{~h}$ on day 11, as described in the Experiment IIa. Since the saline-control groups are identical in Experiments IIa and $\mathrm{IIb}$, the data are considered together as one single group ('saline control') for analysis. The animals' body weights were recorded for 10 days during the injections. Animals were killed at $1130 \mathrm{~h}$ (30 min after the last injection). 
Since $40 \mathrm{mg} / \mathrm{kg}$ is a relatively high dose of morphine in opiate-naïve animals, possibly leading to symptoms of morphine overdose, including respiratory depression (Hurwitz \& Fischer 1984) and lethality (Borron et al. 2002), we could not examine the effects of acute morphine treatment at $40 \mathrm{mg} / \mathrm{kg}$. We followed the Principles of Laboratory Animal Care (NIH Publication No. 86-23, 1996), and the specific protocols were approved by the Rockefeller University Animal Care and Use Committee.

\section{Preparation of RNA extracts}

Each rat brain was removed from the skull and placed in a chilled rat brain matrix (Electron Microscopy Sciences, Ft Washington, PA, USA). Coronal slices containing the brain regions of interest were removed from the matrix and placed on a chilled Petri dish. Dissection was carried out under a dissecting microscope using razor blades and forceps. The brain regions of interest were identified according to the Rat Brain Stereotaxic Coordinates (Paxinos \& Watson 1986), as described in detail in an earlier publication (Maggos et al. 1997). Six brain and pituitary regions, including the anterior pituitary, neurointermediate lobe/posterior lobe of the pituitary (NIL/PL), CPu, nucleus accumbens (NAc) core and amygdala, lat.hyp, and medial portion of hypothalamus ( $\mathrm{MH}$, including the PVN and arcuate nucleus) were dissected on ice, homogenized in guanidinium thiocyanate buffer and extracted with acidic phenol and chloroform as described earlier (Chomczynski \& Sacchi 1987). After the final ethanol precipitation step, each extract was resuspended in DEPCtreated $\mathrm{H}_{2} \mathrm{O}$ and stored at $-80{ }^{\circ} \mathrm{C}$.

\section{Solution hybridization ribonuclease (RNase) protection-tri- chloroacetic acid (TCA) precipitation assay}

The solution hybridization RNase protection-TCA precipitation protocol has been described in detail in earlier reports (Branch et al. 1992, Zhou et al. 1996). A $2100 \mathrm{bp}$ fragment from the rat MOP-r cDNA, a $538 \mathrm{bp}$ fragment from the rat POMC cDNA, or a $1700 \mathrm{bp}$ fragment from the rat preprodynorphin (ppDyn) cDNA was cloned into the polylinker region of either pSP64 or pSP65 plasmids (Promega) in both the sense and the antisense orientations. A $531 \mathrm{bp}$ fragment from rat hypocretin (or orexin) cDNA was cloned into the polylinker region of $\mathrm{pBC} \mathrm{SK}+$ (Stratagene, La Jolla, CA, USA). A $2 \cdot 5 \mathrm{~kb}$ fragment from the rat CRHR1 cDNA was cloned into the polylinker region of pcDNA (Promega). The plasmid pS/E (a pSP65 derivative) was used to synthesize riboprobe for the $18 \mathrm{~S}$ rRNA to determine total RNA. ${ }^{33}$ P-labeled cRNA antisense probes and unlabeled cRNA sense standards were synthesized using a SP6, T3, or T7 transcription system. A denaturing agarose gel containing $1.0 \mathrm{M}$ formaldehyde showed that a single full-length transcript had been synthesized from each plasmid.

RNA extracts were dried in $1.5 \mathrm{ml}$ Eppendorf tubes and resuspended in $30 \mu \mathrm{l} 2 \times$ TESS $(10 \mathrm{mM} \mathrm{N-tris[hydroxy-}$

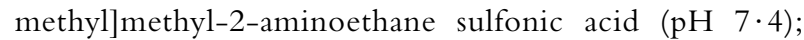
$10 \mathrm{mM}$ EDTA; $0 \cdot 3 \mathrm{M} \mathrm{NaCl} ; 0 \cdot 5 \% \mathrm{SDS})$ that contained 150 000-300 000 c.p.m. of a probe. The samples were covered with mineral oil and hybridized overnight at $75^{\circ} \mathrm{C}$. For RNase treatment, $250 \mu \mathrm{l}$ buffer that contained $0.3 \mathrm{M} \mathrm{NaCl} ; 5 \mathrm{mM}$ EDTA; $10 \mathrm{mM}$ Tris- $\mathrm{HCl}(\mathrm{pH} 7 \cdot 5), 40 \mu \mathrm{g} / \mathrm{ml}$ RNase A (Worthington, Biochemicals, Freehold, NJ, USA) and $2 \mu \mathrm{g} / \mathrm{ml}$ RNase T1 (Calbiochem, San Diego, CA, USA) were added and each sample was incubated at $30^{\circ} \mathrm{C}$ for $1 \mathrm{~h}$. TCA precipitation was effected by the addition of $1 \mathrm{ml}$ solution that contained 5\% TCA and $0 \cdot 75 \%$ sodium pyrophosphate. Precipitates were collected onto a filter in sets of 24 by using a cell harvester (Brandel, Gaithersburg, MD, USA) and were measured in a scintillation counter with liquid scintillant (Beckman Instruments, Palo Alto, CA, USA).

The procedure to measure mRNA levels involved comparison of values obtained from experimental samples (brain extracts) to those obtained for a set of calibration standards. The calibration standards had known amounts of an in vitro sense transcript, whose concentration was determined by optical absorbance at $260 \mathrm{~nm}$. The set of calibration standards included those with no added sense transcript and those that contained between $1 \cdot 25$ and 80 pg sense transcript (Zhou et al. 1996). To determine the total attomoles of each mRNA in each extract, the amounts calculated from the standard curves were multiplied by $5 \cdot 71$ for MOP-r, $2 \cdot 04$ for POMC, $1 \cdot 3$ for orexin, or $1 \cdot 08$ for CRH-R 1 to correct for the difference in length between the sense transcript (2100, 538,531 , or 2500 bases for the MOP-r, POMC, orexin, or CRH-R1 respectively) and the full-length mRNA $(12,1 \cdot 1$, $0 \cdot 7$, or $2.7 \mathrm{~kb}$ for the MOP-r, POMC, orexin, or CRHR1). A new standard curve was generated each time the experimental samples were analyzed and all extracts of a particular tissue were assayed for each mRNA as a group in a single assay.

Total cellular RNA concentrations were measured by hybridization of diluted extracts to a ${ }^{33} \mathrm{P}$-labeled probe complementary to $18 \mathrm{~S}$ rRNA at $75^{\circ} \mathrm{C}$. The calibration standards for this curve contained $10 \mu \mathrm{g}$ Escherichia coli tRNA plus either $0 \cdot 0$ or from $2 \cdot 5$ to $40 \mathrm{ng}$ total RNA from rat brain, whose concentration was determined by optical absorbance at $260 \mathrm{~nm}$.

\section{Radioimmunoassays}

At the time of decapitation, blood from each rat was collected in tubes, placed on ice, and was spun in a refrigerated centrifuge. Plasma was separated and stored at $-40^{\circ} \mathrm{C}$ for hormonal measurements by RIA. Corticosterone and testosterone levels were assayed using a rat corticosterone or testosterone ${ }^{125}$ I kit from ICN Biomedicals (Costa Mesa, CA, USA). ACTH or luteinizing hormone (lat.hyp) immunoreactivity levels were assayed from unextracted plasma by using a kit from Nichols Institute (San Juan Capistrano, CA, USA) or from Amersham Pharmacia Biotech. All values were determined in duplicate in a single assay. 


\section{Data analysis}

In Experiment I, a Student's $t$-test was carried out for each tissue to evaluate the statistical significance of differences between treatment groups. In Experiments IIa and IIb, oneway ANOVA (saline control (controls combined), CIEM, and ASWCIEM) was used followed by Newman-Keuls post hoc tests. To examine the effects of chronic morphine on body weights in Experiment IIa, a Student's t-test was carried out. The accepted level of significance was $P<0 \cdot 05$.

\section{Results}

Effects of acute single-dose morphine $(10 \mathrm{mg} / \mathrm{kg})$

mRNA levels of MOP-r, POMC, orexin, or CRH$\mathbf{R} 1$ in specific brain regions or pituitary As shown in Table 1, acute morphine had no effect on MOP-r mRNA levels in the lat.hyp, amygdala, nucleus accumbens core, or $\mathrm{CPu}$. There were no significant differences in POMC, orexin, or CRH-R1 mRNA levels in the medial hypothalamus, lat.hyp, amygdala, anterior pituitary, or neurointermediate lobe/posterior lobe of the pituitary, following acute morphine.

Plasma levels of ACTH, corticosterone, lat.hyp, or testosterone (Table 1) Although plasma ACTH levels after acute morphine were almost twice as high as in the saline controls, this effect did not reach statistical significance $(t=3 \cdot 38$, d.f. $=13, P=0 \cdot 089)$. However, there were significantly higher levels of plasma corticosterone after acute morphine $(t=10 \cdot 31$, d.f. $=14, P<0 \cdot 01)$. Acute morphine had no effects on either plasma lat.hyp or testosterone levels.
Effects of chronic (10 days) intermittent escalating-dose morphine or $12 \mathrm{~h}$ spontaneous withdrawal from chronic morphine

MOP-r mRNA levels in four specific brain regions In the lat.hyp, one-way ANOVA showed a significant treatment effect $\left(F_{(2,21)}=12 \cdot 2, \quad P<0 \cdot 0005\right.$; Fig. 1A). Although the mean level of MOP-r mRNA after chronic morphine was approximately $24 \%$ lower than the mean saline control level, a Newman-Keuls post hoc test did not show a significant difference. However, spontaneous $12 \mathrm{~h}$ withdrawal from chronic intermittent escalating-dose morphine led to a significant increase in MOP-r mRNA levels in the lat.hyp $(P<0 \cdot 01)$. In addition, the MOP-r mRNA levels in the morphine-withdrawal group were significantly higher than the chronic morphine group $(P<0 \cdot 01)$.

In the amygdala, neither chronic morphine nor its withdrawal had any effect on MOP-r mRNA levels (Fig. 1A).

In the $\mathrm{CPu}$, one-way ANOVA showed a significant treatment effect $\left(F_{(2,21)}=5 \cdot 71, P<0 \cdot 05\right.$; Fig. 1B). Chronic morphine had no effects on MOP-r mRNA levels. However, spontaneous morphine withdrawal led to a significant increase in MOP-r mRNA levels in the $\mathrm{CPu}(P<0 \cdot 05)$. In addition, the MOP-r mRNA levels in the morphine-withdrawal group were significantly higher than the chronic morphine group $(P<0 \cdot 05)$.

In the nucleus accumbens core, one-way ANOVA showed a significant treatment effect $\left(F_{(2,17)}=6 \cdot 03, P<0 \cdot 05\right.$; Fig. 1B). Chronic morphine had no effects on MOP-r mRNA levels in this region. However, spontaneous withdrawal resulted in a significant increase in MOP-r mRNA levels in the nucleus accumbens core $(P<0 \cdot 05)$. In addition, the MOP-r mRNA levels in the withdrawal group were significantly higher than the chronic morphine group $(P<0 \cdot 05)$.

Table 1 Effects of acute single-dose morphine (10 mg/kg, i.p.) on mRNA levels (attomole/ $\mu \mathrm{g}$ RNA) of mu opioid receptor (MOP-r), POMC, orexin, or $\mathrm{CRH}-\mathrm{R} 1$ in the lateral hypothalamus, medial hypothalamus, amygdala, caudate-putamen, nucleus accumbens core, anterior pituitary, or neurointermediate lobe/posterior lobe of the pituitary (NIL/PL), and on plasma levels of ACTH (pg/ml), corticosterone (ng/ml), luteinizing hormone $(\mathrm{LH} ; \mathrm{ng} / \mathrm{ml})$ and testosterone $(\mathrm{ng} / \mathrm{ml})$. Data shown in tables are treatment group means \pm s.E.M.

\begin{tabular}{|c|c|c|c|}
\hline & & Saline control & Acute morphine \\
\hline \multirow[t]{2}{*}{ Lateral hypothalamus } & MOP-r & $0 \cdot 30 \pm 0 \cdot 03$ & $0 \cdot 28 \pm 0 \cdot 04$ \\
\hline & Orexin & $5 \cdot 1 \pm 0 \cdot 42$ & $4 \cdot 8 \pm 0 \cdot 34$ \\
\hline Medial hypothalamus & POMC & $14 \pm 1 \cdot 7$ & $11 \pm 1 \cdot 8$ \\
\hline \multirow[t]{2}{*}{ Amygdala } & MOP-r & $0 \cdot 17 \pm 0 \cdot 02$ & $0 \cdot 20 \pm 0 \cdot 01$ \\
\hline & POMC & $2 \cdot 0 \pm 0 \cdot 38$ & $1 \cdot 7 \pm 0 \cdot 28$ \\
\hline Caudate-putamen & MOP-r & $0 \cdot 13 \pm 0 \cdot 02$ & $0 \cdot 15 \pm 0 \cdot 01$ \\
\hline Nucleus accumbens core & MOP-r & $0 \cdot 28 \pm 0 \cdot 03$ & $0 \cdot 31 \pm 0 \cdot 02$ \\
\hline \multirow[t]{2}{*}{ Anterior pituitary } & POMC & $720 \pm 42$ & $693 \pm 45$ \\
\hline & CRH-R1 & $0.95 \pm 0.07$ & $0 \cdot 93 \pm 0 \cdot 08$ \\
\hline NIL/PL & POMC & $21631 \pm 1002$ & $17216 \pm 1535$ \\
\hline \multirow{4}{*}{ Plasma } & ACTH & $193 \pm 35$ & $380 \pm 90^{+}$ \\
\hline & Corticosterone & $234 \pm 36$ & $398 \pm 36^{*}$ \\
\hline & $\mathrm{LH}$ & $0 \cdot 25 \pm 0 \cdot 04$ & $0 \cdot 26 \pm 0 \cdot 04$ \\
\hline & Testosterone & $0 \cdot 87 \pm 0 \cdot 20$ & $0 \cdot 54 \pm 0 \cdot 14$ \\
\hline
\end{tabular}

Significant differences are indicated: $* P<0 \cdot 01\left({ }^{\dagger} P=0 \cdot 09\right)$. 
A Lateral hypothalamus and amygdala

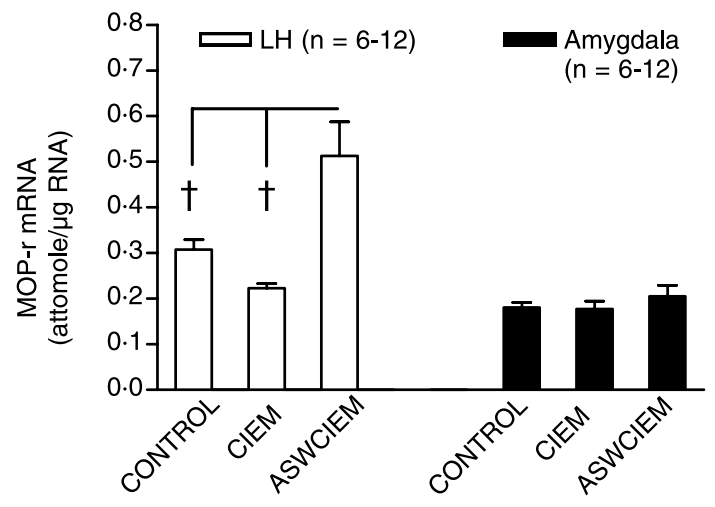

B

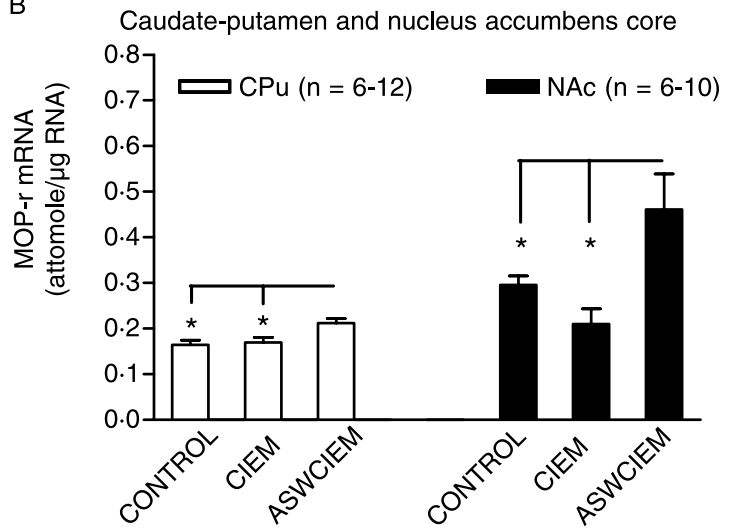

Figure 1 Effects of chronic (10 days) intermittent escalating-dose morphine (CIEM) or its $12 \mathrm{~h}$ acute spontaneous withdrawal (ASWCIEM) on mu opioid receptor (MOP-r) mRNA levels (attomole/ $\mu \mathrm{g} R \mathrm{RA}$ ) in the (A) lateral hypothalamus (LH) or amygdala and (B) caudate-putamen $(\mathrm{CPu})$ or nucleus accumbens (NAc) core. Data shown are treatment group means + S.E.M. Significant differences by Newman-Keuls post hoc test are indicated: ${ }^{*} P<0 \cdot 05$ or ${ }^{\dagger} P<0 \cdot 01$.

POMC mRNA levels in the brain and pituitary Figure 2A shows POMC mRNA levels in the RNA extracts from the medial hypothalamus or amygdala. Neither chronic intermittent escalating-dose morphine nor its spontaneous withdrawal resulted in any change of POMC mRNA levels in these two regions.

In the anterior pituitary, one-way ANOVA showed a significant treatment effect $\left(F_{(2,23)}=7 \cdot 96, P<0 \cdot 01\right.$; Fig. 2B). There was no significant effect of chronic morphine on POMC mRNA levels. However, spontaneous withdrawal led to a significant increase in POMC mRNA levels in the anterior pituitary $(P<0 \cdot 01)$. In addition, the POMC mRNA levels in the withdrawal group were significantly higher than the chronic morphine group $(P<0 \cdot 05)$.

No differences were found following chronic morphine or its withdrawal on POMC mRNA levels in the neurointermediate lobe/posterior lobe of the pituitary (Fig. 2B).
A

Medial hypothalamus and amygdala

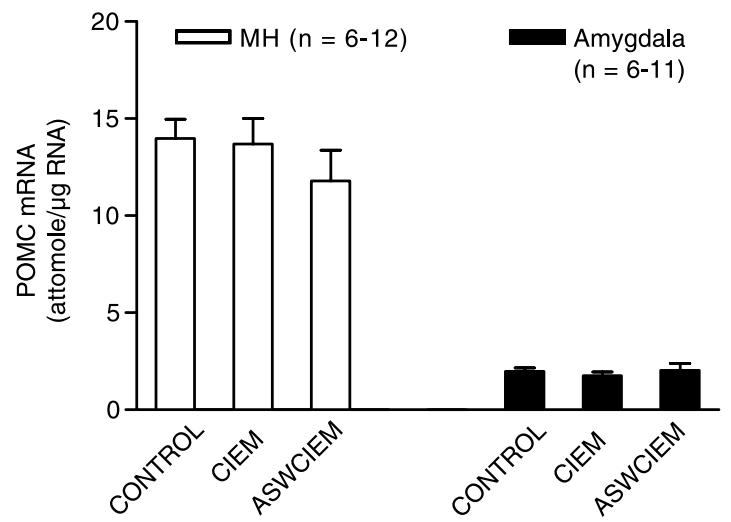

B

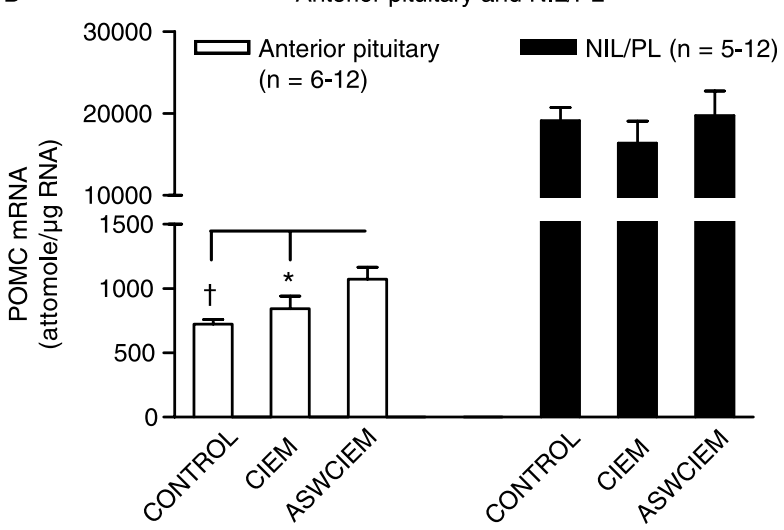

Figure 2 Effects of chronic (10 days) intermittent escalating-dose morphine (CIEM) or its $12 \mathrm{~h}$ acute spontaneous withdrawal (ASWCIEM) on POMC mRNA levels (attomole/ $\mu \mathrm{g}$ RNA) in the (A) medial hypothalamus ( $\mathrm{MH}$ ) or amygdala and (B) anterior pituitary or neurointermediate lobe/posterior lobe of the pituitary (NIL/PL). Data shown are treatment group means + s.E.M. Significant differences are indicated: ${ }^{*} P<0 \cdot 05$ or ${ }^{+} P<0 \cdot 01$.

Orexin and ppDyn mRNA levels in the lateral hypothalamus Figure $3 \mathrm{~A}$ shows orexin and ppDyn mRNA levels in the same RNA extracts from the lat.hyp as those used in assays of MOP-r mRNA (Fig. 1A). One-way ANOVA showed a significant treatment effect on orexin mRNA levels $\left(F_{(2,21)}=18 \cdot 16, P<0 \cdot 0001\right)$. While there was no significant effect of chronic morphine on orexin mRNA levels, spontaneous morphine withdrawal led to a significant increase in orexin mRNA levels in the lat.hyp $(P<0 \cdot 001)$. In addition, orexin mRNA levels in the morphine-withdrawal group were significantly higher than the chronic morphine group $(P<0 \cdot 001)$.

Neither chronic intermittent escalating-dose morphine nor its spontaneous withdrawal resulted in any change of the ppDyn mRNA levels in the lat.hyp (Fig. 3A).

Orexin mRNA in the lat.hyp coexpress with ppDyn (Chou et al. 2001) and MOP-r (Georgescu et al. 2003). 
A

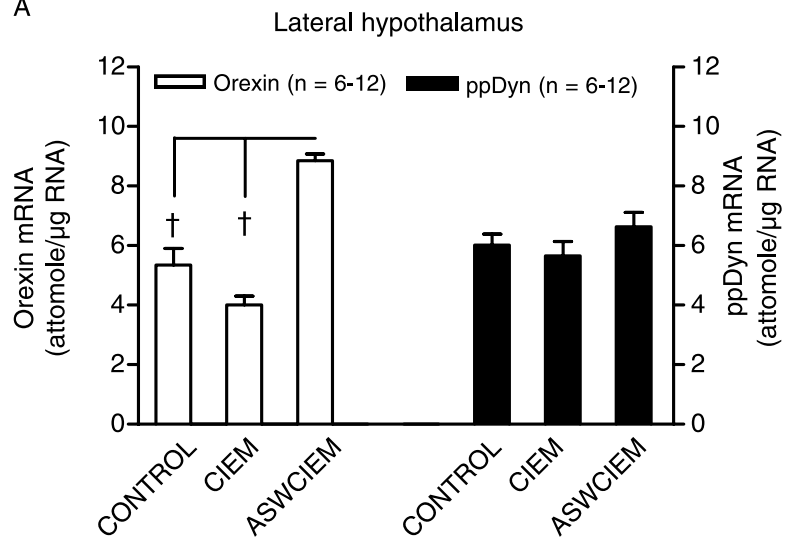

B

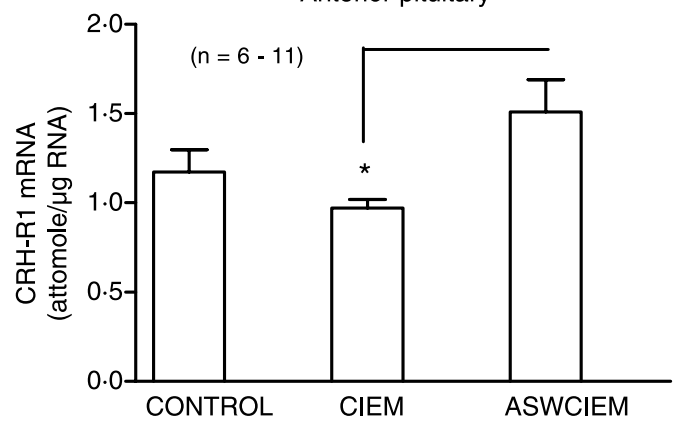

Figure 3 Effects of chronic (10 days) intermittent escalating-dose morphine (CIEM) or its $12 \mathrm{~h}$ acute spontaneous withdrawal (ASWCIEM) on mRNA levels (attomole/ $\mu$ g RNA) of (A) orexin or preprodynorphin (ppDyn) in the lateral hypothalamus (LH) and (B) $\mathrm{CRH}$ type 1 receptor (CRH-R1) in the anterior pituitary. Data shown are treatment group means + S.E.M. Significant differences are indicated: ${ }^{*} P<0 \cdot 05$ or $^{\dagger} P<0 \cdot 001$.

Since all of MOP-r, orexin, and ppDyn mRNA levels were determined in the lat.hyp of each rat, we were able to examine the relationship between the levels of mRNAs of three genes. Therefore, we examined whether orexin mRNA levels were related to either MOP-r or ppDyn mRNA levels. There was no correlation between the orexin, MOP-r, or ppDyn mRNA levels in the lat.hyp (data not shown).

CRH-R1 mRNA levels in the anterior pituitary One-way ANOVA just failed to show a significant treatment effect on CRH-R1 mRNA levels in the anterior pituitary $\left(F_{(2,19)}=3 \cdot 25, P=0 \cdot 06\right.$; Fig. 3B). Chronic morphine had no effects on CRH-R1 mRNA levels. Spontaneous morphine withdrawal did not lead to a significant increase in the CRH-R1 mRNA levels. However, there were significantly higher CRH-R1 mRNA levels in the morphine-withdrawal group than in the chronic morphine group in the anterior pituitary $(P<0 \cdot 05)$.
Effects of chronic (10 days) intermittent escalating-dose morphine or $12 \mathrm{~h}$ spontaneous withdrawal from chronic morphine on body weight, and plasma levels of ACTH, corticosterone, lat.hyp, and testosterone

Body weight $\mathrm{R}$ ats that received saline injections $(n=12)$ had a body weight gain from day $1(257 \pm 4 \mathrm{~g})$ to day 10 $(271 \pm 4 \mathrm{~g})$. However, the animals that received morphine injections $(n=12)$ showed no body weight gain from day 1 $(257 \pm 2 \mathrm{~g})$ to day $10(255 \pm 3 \mathrm{~g})$. By day 10 , body weights in the chronic morphine group were significantly lower than those in the saline-control group $(t=9 \cdot 97$, d.f. $=22$, $P<0 \cdot 005)$.

Plasma levels of ACTH, corticosterone, lat.hyp, and testosterone One-way ANOVA showed a significant treatment effect on plasma ACTH levels $\left(F_{(2,30)}=45 \cdot 64\right.$, $P<0 \cdot 0001$; Fig. 4A). While there was no significant effect of chronic morphine, morphine withdrawal led to a significant increase in plasma ACTH levels, compared both with the
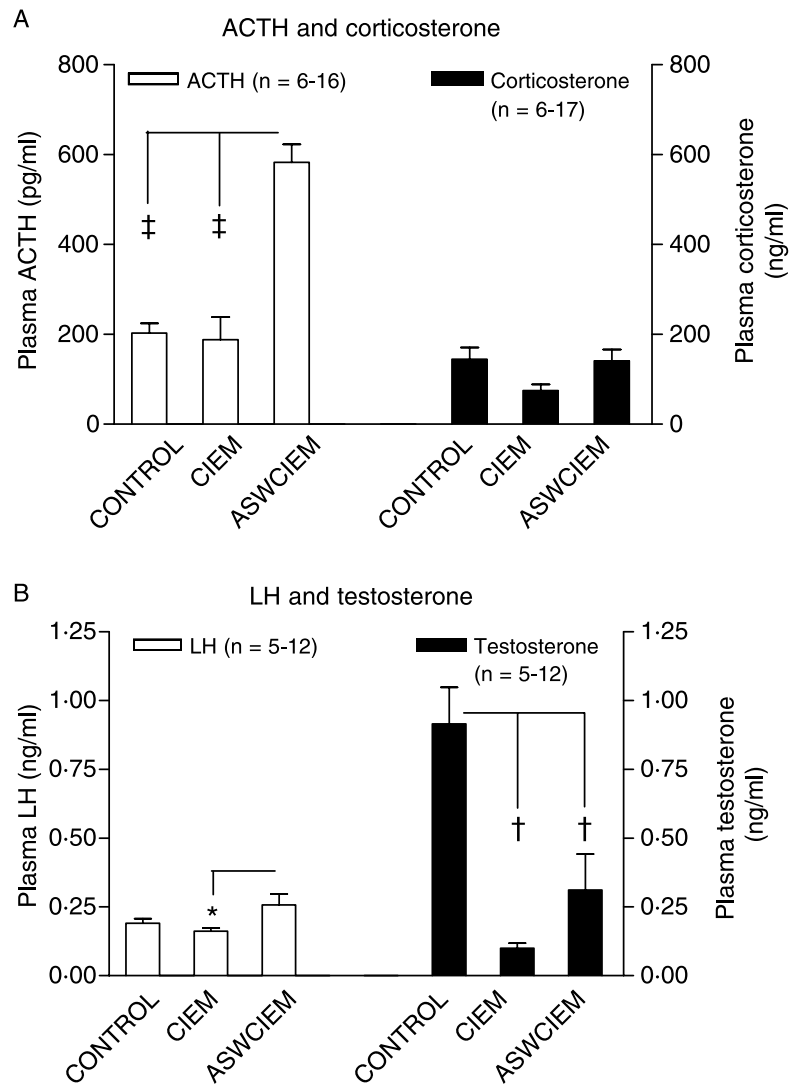

Figure 4 Effects of chronic (10 days) intermittent escalating-dose morphine (CIEM) or its $12 \mathrm{~h}$ acute spontaneous withdrawal (ASWCIEM) on plasma hormonal levels of (A) ACTH $(\mathrm{pg} / \mathrm{ml})$ or corticosterone $(\mathrm{ng} / \mathrm{ml})$ or $(B)$ luteinizing hormone $(\mathrm{LH} ; \mathrm{ng} / \mathrm{ml})$ or testosterone $(\mathrm{ng} / \mathrm{ml})$. Data shown are treatment group means + S.E.M. Significant differences are indicated: ${ }^{*} P<0 \cdot 05,{ }^{\dagger} P<0 \cdot 01$, or ${ }^{\ddagger} P<0 \cdot 001$. 
saline-control group $(P<0 \cdot 001)$, and to the chronic morphine group $(P<0 \cdot 001)$. Neither chronic morphine nor its withdrawal resulted in any change in plasma corticosterone levels (Fig. 4A).

One-way ANOVA showed a marginally significant treatment effect on plasma lat.hyp levels $\left(F_{(2,19)}=3 \cdot 36, P=0 \cdot 05\right.$; Fig. 4B). While there was no significant effect of either chronic morphine or its withdrawal on plasma lat.hyp levels compared with controls, plasma lat.hyp levels were significantly higher in the withdrawal group than in the chronic morphine group $(P<0 \cdot 05)$.

One-way ANOVA showed a significant treatment effect on plasma testosterone levels $\left(F_{(2,21)}=11 \cdot 6, \quad P<0 \cdot 0005\right.$; Fig. 4B). Chronic morphine led to a significant decrease in plasma testosterone levels $(P<0 \cdot 01)$, which was still found following $12 \mathrm{~h}$ withdrawal $(P<0 \cdot 01)$.

\section{Discussion}

\section{MOP-r $m R N A$ responses in acute morphine withdrawal}

In several studies of coupling of MOP-rs to $\mathrm{K}+$ channels, it has been reported that arcuate nucleus $\beta$-endorphin neurons in the female guinea pig develop a high degree of tolerance to morphine compared with some other neurons in the same region, and the decrease in the efficacy and/or potency of the response to MOP-r agonists in the mediobasal hypothalamus is due in part to the downregulation of the MOP-r (Kelly et al. 1990, Zhang et al. 1996). Furthermore, a decreased MOP-r mRNA level was found in the mediobasal hypothalamus of the female guinea pig after chronic morphine (Ronnekleiv et al. 1996). In this study, we examined the rat lat.hyp after 10 days of chronic intermittent escalating-dose morphine administration, and found no significant effect on MOP-r mRNA levels. We extended our studies to investigate the effects of $12 \mathrm{~h}$ spontaneous morphine withdrawal, and found an increase in MOP-r mRNA levels in the lat.hyp. This increase in MOP-r mRNA levels after morphine withdrawal suggests an enhanced MOP-r biosynthesis, although it cannot be determined from assays of mRNA levels alone which steps (MOP-r gene transcription, processing, and/or degradation of mRNA) are affected. To the best of our knowledge, no effect of either chronic morphine or its withdrawal on MOP-r mRNA stability has been reported. Indeed, neither chronic morphine nor opiate antagonists have been reported to change the size of the MOP-r mRNA molecule, which suggests that the MOP-r mRNA stability is unaltered by chronic opiate treatment (Brodsky et al. 1995).

Different studies have examined the effect of chronic opioid agonists or their withdrawal on MOP-r mRNA levels in different brain regions (Brodsky et al. 1995, Buzas et al. 1996, Ronnekleiv et al. 1996, Castelli et al. 1997, Sehba et al. 1997, Duttaroy \& Yoburn 2000). The results obtained are conflicting; a decrease (Ronnekleiv et al. 1996, Duttaroy \& Yoburn 2000), an increase (Sehba et al. 1997), or no change
(Brodsky et al. 1995, Buzas et al. 1996, Castelli et al. 1997) have been reported, and these apparently contradictory results may depend on differences in the brain regions examined, exposure time, dose, and route of the opioid agonist administered. In many of the previous studies, morphine or opioid agonists were chronically administered by minipumps or pellets (Brodsky et al. 1995, Ronnekleiv et al. 1996, Sehba et al. 1997, Duttaroy \& Yoburn 2000). This differs from our morphine experiments using an intermittent pattern of administration, in which the animal could experience both rewarding effects and chronic stress induced by repeated morphine injection and withdrawal.

We specifically selected several brain regions considered to play an important role in the reinforcing or motivational effects of drugs of abuse, such as the nucleus accumbens core, amygdala, lat.hyp, and $\mathrm{CPu}$ (e.g. Kreek \& Koob 1998). Consistent with several earlier reports (Brodsky et al. 1995, Buzas et al. 1996, Castelli et al. 1997), we found that chronic morphine did not modify the steady-state MOP-r mRNA levels in the brain regions listed earlier. In contrast, spontaneous morphine withdrawal led to an increase in MOP-r mRNA levels in the nucleus accumbens core, lat.hyp, and $\mathrm{CPu}$, but not in the amygdala. Our data clearly showed that morphine withdrawal increases MOP-r mRNA levels in a region-specific manner, and therefore suggest that the observed increase of MOP-r agonist responses may be due to an increased $M O P-r$ gene expression in these brain regions (Alcaraz et al. 1993, Johnson \& Napier 2000). A body of evidence suggests that opioid agonists exert inhibitory effects on endogenous opioid peptide gene expression through an opioid receptor-mediated mechanism (e.g. Morris et al. 1988). Here, our finding of increased MOP-r gene expression by morphine withdrawal suggests that opioid agonists also have an inhibitory effect on MOP-r gene expression.

Of note, there is no consensus that chronic opioid agonist administration disrupts MOP-r binding, signal transduction, or gene expression in different rat brain regions. For instance, an earlier study has found an increased MOP-r-binding density after chronic heroin self-administration in the hypothalamus, but not amygdala (Sim-Selley et al. 2000). However, a decrease in MOP-r-stimulated G-protein levels (as reflected by GTP $\gamma \mathrm{S}$ binding) is only found in the amygdala, but not in the hypothalamus, after chronic morphine or heroin selfadministration (Sim et al. 1996, Sim-Selley et al. 2000, Kruzich et al. 2003). In this study, spontaneous withdrawal from chronic morphine altered MOP-r mRNA levels in the hypothalamus, but not in the amygdala.

\section{Stress responses in acute morphine withdrawal}

In this study, we also found that: (1) acute morphine exposure to opiate-naive rats stimulated the HPA activity, as reflected by an elevation of plasma ACTH and corticosterone levels $30 \mathrm{~min}$ after a single dose of morphine at $10 \mathrm{mg} / \mathrm{kg}$ dose. (2) After 10 days of chronic intermittent escalating-dose morphine administration, however, the levels of both plasma ACTH and 
corticosterone did not show any responses to morphine, indicating adaptation or tolerance of HPA activity to chronic escalating-dose morphine. (3) Following spontaneous withdrawal for $12 \mathrm{~h}$ from this chronic morphine administration, there was a significant elevation of plasma ACTH levels. These results confirm earlier findings of HPA axis activation by morphine withdrawal after tolerance has developed following chronic morphine exposure (Buckingham \& Cooper 1984, Ignar \& Kuhn 1990, Martinez et al. 1990, Milanes et al. 2002). An elevation of corticosterone levels by morphine withdrawal has been reported (Lightman \& Young 1988, Martinez et al. 1990), but this is observed after immediate (15 min to $4 \mathrm{~h}$ ) morphine withdrawal precipitated by naloxone. In our study, which examined spontaneous withdrawal at the $12 \mathrm{~h}$ time point, there was no elevation in plasma corticosterone levels, suggesting that corticosterone levels had already returned to the basal levels at this time point.

It has recently been reported that morphine-induced place preference is not seen in orexin knockout mice, suggesting that the excitation of brain orexin neurons and/or the tonic activation of orexin receptors are specifically required for the rewarding effect of opiates (Narita et al. 2006). In addition, naloxone-precipitated morphine withdrawal induces orexin gene expression in orexin-LacZ reporter mice, and orexin knockout mice have attenuated opiate physical dependence as reflected by reduced withdrawal signs (Georgescu et al. 2003). In the lat.hyp, a subpopulation of orexin neurons (around 50\%) expresses MOP-r (Georgescu et al. 2003), and nearly all orexin neurons (94\%) express ppDyn mRNA (Chou et al. 2001).

In this study, quantitative and sensitive solution hybridization assays were used to measure mRNA levels of orexin, MOP-r, and ppDyn in each lateral hypothalamic RNA extract. We found a significant increase in orexin and MOP-r mRNA levels after acute spontaneous withdrawal, with no change in ppDyn mRNA levels. Within the same animals, however, there was no correlation between these two parallel increases. Therefore, this suggests that the regulation by acute morphine withdrawal of lat.hyp orexin gene expression is not directly related to either the MOP-r or $p p D y n$ gene regulation in the same region.

MOP-r is also expressed in the lat.hyp neurons, which do not express orexin, but which also respond to morphine withdrawal (Georgescu et al. 2003). Since our assays could not differentiate these cells from the orexin neuron subpopulation, the MOP-r mRNA increases observed in this study may be due to both the orexin and the non-orexin cells. This may also account for the lack of correlation between the orexin and the MOP-r mRNA increases in morphine withdrawal. Although melanin-concentrating hormone $(\mathrm{MCH})$ neurons are highly expressed in the lat.hyp and several studies have suggested them to be involved in reward and motivated behaviors (e.g. Duncan et al. 2005, Georgescu et al. 2005), it has been found that the $\mathrm{MCH}$ neurons do not express MOP-r, and do not respond to morphine withdrawal (Georgescu et al. 2003).
In summary, the present study showed that morphine withdrawal increases MOP-r mRNA levels in a brain regionspecific manner. In animal behavioral studies, a growing body of evidence suggests a novel role for the orexins in the neurobiological processes of drug reward and other motivated behaviors (Boutrel et al. 2005, Harris et al. 2005). Our finding of an increase in orexin gene expression in the lat.hyp in the setting of morphine withdrawal supports this possible role.

\section{Acknowledgements}

The authors would like to thank J Huynh for his excellent technical assistance. The authors would also like to thank Dr $G$ Uhl for the rat MOP-r cDNA; Dr L de Lecea for the rat hypocretin (or orexin) cDNA; Dr J Roberts for the rat POMC cDNA; Drs J Douglass and O Civelli for the rat ppDyn cDNA; Dr W Vale for the CRH-R1 cDNA; and Drs $\mathrm{T}$ Nilsen and P Maroney for the 18S DNA. The work was supported by NIDA Research Center Grant DA-P60-05130 and DA-00049 (M J K). The authors declare that there is no conflict of interest that would prejudice the impartiality of this scientific work.

\section{References}

Alcaraz C, Vargas M, Fuente T \& Milanes M 1993 Chronic naloxone treatment induces supersensitivity to a mu but not to a kappa agonist at the hypothalamic-pituitary-adrenocortical axis level. Journal of Pharmacology and Experimental Therapeutics 266 1602-1606.

Borgland S, Taha S, Sarti F, Fields H \& Bonci A 2006 Orexin A in the VTA is critical for the induction of synaptic plasticity and behavioral sensitization to cocaine. Neuron 49 589-601.

Borron S, Monier C, Risede P \& Baud F 2002 Flunitrazepam variably alters morphine, buprenorphine, and methadone lethality in the rat. Human and Experimental Toxicology 21 599-605.

Boutrel B, Kenny PJ, Specio SE, Martin-Fardon R, Markou A, Koob GF \& de Lecea L 2005 Role for hypocretin in mediating stress-induced reinstatement of cocaine-seeking behavior. PNAS 102 19168-19173.

Branch A, Unterwald EM, Lee S \& Kreek MJ 1992 Quantitation of preproenkephalin mRNA levels in brain regions from Fischer rats following chronic cocaine treatment using recently developed solution hybridization assay. Molecular Brain Research 14 231-238.

Brodsky M, Elliott K, Hynansky A \& Inturrisi CE 1995 CNS levels of mu opioid receptor (MOR-1) mRNA during chronic treatment with morphine or naltrexone. Brain Research Bulletin 38 135-141.

Buckingham JC \& Cooper T 1984 Differences in hypothalamo-pituitaryadrenal activity in rats after acute and prolonged treatment with morphine. Neuroendocrinology 38 411-417.

Buzas B, Rosenberger J \& Cox BM $1996 \mathrm{Mu}$ and delta opioid receptor gene expression after chronic treatment with opioid agonist. Neuroreport 7 1505-1508.

Castelli MP, Melis M, Mameli M, Fadda P, Diaz G \& Gessa GL 1997 Chronic morphine and naltrexone fail to modify mu-opioid receptor mRNA levels in the rat brain. Molecular Brain Research 45 149-153.

Chomczynski P \& Sacchi N 1987 Single-step method of RNA isolation by acid guanidinium thiocyanate-phenol-chloroform extraction. Analytical Biochemistry 162 156-159

Chou TC, Lee CE, Lu J, Elmquist JK, Hara J, Willie JT, Beuchmann CT, Chemelli RM, Sakurai T, Yanagisawa M et al. 2001 Orexin (hypocretin) neurons contain dynorphin. Journal of Neuroscience 21 RC168 1-6. 
Culpepper-Morgan JA \& Kreek MJ 1997 Hypothalamic-pituitary-adrenal axis hypersensitivity to naloxone in opioid dependence: a case of naloxone induced withdrawal. Metabolism 46 130-134.

Duncan EA, Proulx K \& Woods SC 2005 Central administration of melaninconcentrating hormone increases alcohol and sucrose/quinine intake in rats. Alcoholism, Clinical and Experimental Research 29 958-964.

Duttaroy A \& Yoburn BC 2000 In vivo regulation of mu-opioid receptor density and gene expression in CXBK and outbred Swiss Webster mice. Synapse 37 118-124.

Eisenberg RM 1980 Effects of naloxone on plasma corticosterone in the opiate-naive rat. Life Sciences 26 935-943.

Georgescu D, Zachariou V, Barrot M, Mieda M, Willie JT, Eisch AJ, Yanagisawa M, Nestler EJ \& Dileone RJ 2003 Involvement of the lateral hypothalamic peptide orexin in morphine dependence and withdrawal. Journal of Neuroscience 23 3106-3111.

Georgescu D, Sears RM, Hommel JD, Barrot M, Bolanos CA, Marsh DJ, Bednarek MA, Bibb JA, Maratos-Flier E, Nestler EJ et al. 2005 The hypothalamic neuropeptide melanin-concentrating hormone acts in the nucleus accumbens to modulate feeding behavior and forced-swim performance. Journal of Neuroscience 25 2933-2940.

Harris GC, Wimmer M \& Aston-Jones G 2005 A role for lateral hypothalamic orexin neurons in reward seeking. Nature 437 556-559.

Hurwitz A \& Fischer HR 1984 Effects of morphine and respiratory depression on sulfobromophthalein disposition in rats. Anesthesiology 60 537-560.

Ignar DM \& Kuhn CM 1990 Effects of specific mu and kappa opiate tolerance and abstinence on hypothalamo-pituitary-adrenal axis secretion in the rat. Journal of Pharmacology and Experimental Therapeutics 225 1287-1295.

Johnson PI \& Napier TC 2000 Ventral pallidal injections of a mu antagonist block the development of behavioral sensitization to systemic morphine. Synapse 38 61-70.

Kelly MJ, Loose MD \& Ronnekleiv OK 1990 Opioids hyperpolarize betaendorphin neurons via mu-opioid activiation of a potassium conductance. Neuroendocrinology 52 268-275.

Kosten TR, Kreek MJ, Raghunath J \& Kleber HD 1986 Cortisol levels during naltrexone maintenance treatment in ex-opiate addicts. Biological Psychiatry $21217-220$.

Kreek MJ \& Hartman N 1982 Chronic use of opioids and antipsychotic drugs: side effects, effects on endogenous opioids and toxixity. Annals of the New York Academy of Sciences 398 151-172.

Kreek MJ \& Koob GF 1998 Drug dependence: stress and dysregulation of brain reward pathways. Drug and Alcohol Dependence $5123-47$.

Kreek MJ, Borg L, Zhou Y \& Schluger J 2002 Relationships between endocrine functions and substance abuse syndromes: heroin and related short-acting opiates in addiction contrasted with methadone long-acting opioid agonists used in pharmacotherapy of addiction. In Hormones, Brain and Behavior, pp 781-830. Ed. D Pfaff. San Diego: Academic Press.

Kruzich PJ, Chen AC, Unterwald EM \& Kreek MJ 2003 Subject-regulated dosing alters morphine self-administration behavior and morphinestimulated [35S] GTPgammaS binding. Synapse 47 243-249.

de Lecea L, Kilduff TS, Peyron C, Gao XB, Foye PE, Danielson PE, Fukuhara C, Battenberg ELF, Gautvik VT, Bartlett FS, II. et al. 1998 The hypocretins: hypothalamus-specific peptides with neuroexcitatory activity. PNAS 95 322-327.

Leri F, Zhou Y, Goddard B, Cummins E \& Kreek MJ 2006 Effects of high dose methadone maintenance on cocaine place conditioning, cocaine selfadministration, and mu-opioid receptor mRNA expression in the rat brain. Neuropsychopharmacology 31 1462-1474.

Lightman SL \& Young WS, III. 1988 Corticotropin-releasing factor, vasopressin and POMC mRNA responses to stress and opiates in rats. Journal of Physiology 403 511-523.

Maggos CE, Spangler R, Zhou Y, Schlussman SD, Ho A \& Kreek MJ 1997 Quantitation of dopamine transporter mRNA in the rat brain: mapping, effects of 'binge' cocaine administration and withdrawal. Synapse 26 55-61.

Martinez JA, Vargas ML, Fuente T, Garcia JDR \& Milanes MV 1990 Plasma beta-endorphin and cortisol levels in morphine-tolerant rats and in naloxoneinduced withdrawal. European Journal of Pharmacology 182 117-123.
Milanes MV, Laorden ML, Angel E, Tankosic P \& Burlet A 2002 Effect of naloxone-precipitated morphine withdrawal on $\mathrm{CRH}$ and vasopressin mRNA expression in the rat hypothalamic paraventricular nucleus. Neuroscience Letters 334 58-62.

Morris J, Hollt V \& Herz A 1988 Opioid gene expression in rat striatum is modulated via opioid receptors: evidence from localized receptor inactivation. Neuroscience Letters $\mathbf{8 9} 80-84$.

Narita M, Nagumo Y, Hashoto S, Khotib J, Miyatake M, Sakurai T, Shioda S \& Suzuki T 2006 Direct involvement of orexinergic systems in the activation of mesolimbic dopamine pathway and related behaviors induced by morphine. Journal of Neuroscience 26 398-405.

Nikolarakis KE, Almeida OFX \& Herz A 1987 Feedback inhibition of opioid peptide release in the hypothalamus of the rat. Neuroscience 23 143-148.

Paxinos G \& Watson C 1986 The Rat Brain in Stereotaxic Coordinates. 2nd edn, New York: Academic Press.

Pilcher WH \& Joseph SA 1984 Co-localization of CRF-ir perikarya and ACTH-ir fibers in rat brain. Brain Research 299 91-102.

Ronnekleiv OK, Bosch MA, Cunningham MJ, Wagner EJ, Grandy DK \& Kelly MJ 1996 Downregulation of mu opioid receptor mRNA in the mediobasal hypothalamus of the guinea pig following morphine treatment. Neuroscience Letters 216 129-132.

Saper CB, Scammell TE \& Lu J 2005 Hypothalamic regulation of sleep and circadian rhythms. Nature 437 1257-1263.

Schluger JH, Ho A, Borg L, Porter M, Maniar S, Gunduz M, Perret G, King A \& Kreek MJ 1998 Nalmefene causes greater hypothalamic-pituitaryadrenal axis activation than naloxone in normal volunteers: implications for the treatment of alcoholism. Alcoholism, Clinical and Experimental Research 22 $1430-1436$.

Sehba F, Duttaroy A, Shah S, Chen B, Carroll J \& Yoburn BC 1997 In vivo homologous regulation of mu-opioid receptor gene expression in the mouse. European Journal of Pharmacology 339 33-41.

Sim LJ, Selley DE, Dworkin SI \& Childers SR 1996 Effects of chronic morphine administration on mu opioid receptor-stimulated [35S]GTPgamma S autoradiography in rat brain. Journal of Neuroscience 16 2684-2692.

Sim-Selley LJ, Selley DE, Vogt LJ, Childers SR \& Martin TJ 2000 Chronic heroin self-administration desensitizes mu opioid receptor-activated G-proteins in specific regions of rat brain. Journal of Neuroscience $\mathbf{2 0}$ 4555-4562.

Volavka J, Cho D, Mallya A \& Bauman J 1979 Naloxone increases ACTH and cortisol levels in man. New England Journal of Medicine 300 1056-1057.

Winsky-Sommerer R, Boutrel B \& de Lecea L 2005 Stress and arousal: the corticotrophin-releasing factor/hypocretin circuitry. Molecular Neurobiology 32 285-294.

Zhang G, Lagrange AH, Ronnekleiv OK \& Kelly MJ 1996 Tolerance of hypothalamic beta-endorphin neurons to mu opioid receptor activation following chronic morphine. Journal of Pharmacology and Experimental Therapeutics 277 551-558.

Zhou Y, Spangler R, LaForge KS, Maggos C, Ho A \& Kreek MJ 1996 Modulation of CRF-R1 mRNA in rat anterior pituitary by dexamethasone: correlation with POMC mRNA. Peptides 17 435-441.

Zhou Y, Spangler R, Maggos CE, Wang XM, Han JS, Ho A \& Kreek MJ 1999 Hypothalamic-pituitary-adrenal activity and pro-opiomelanocortin mRNA levels in the hypothalamus and pituitary of the rat are differentially modulated by acute intermittent morphine with or without water restriction stress. Journal of Endocrinology 163 261-267.

Zhou Y, Bendor J, Yuferov V, Schlussmann S, Ho A \& Kreek MJ 2005 Amygdalar vasopressin mRNA increases in acute cocaine withdrawal: evidence for opioid receptor modulation. Neuroscience 134 1391-1397.

Received 12 May 2006

Accepted 5 July 2006

Made available online as an Accepted Preprint 1 August 2006 